\title{
PROBLEM KONSTYTUCYJNOŚCI SKLADU OBECNEJ KRAJOWEJ RADY SĄDOWNICTWA W POLSCE
}

\begin{abstract}
Streszczenie. Krajowa Rada Sądownictwa została utworzona w Polsce w 1989 r. jako organ konstytucyjny. Jej najważniejszym zadaniem jest stanie na straży niezależności sądów i niezawisłości sędziów. Od początku jest to organ o mieszanym składzie, który tworzą przedstawiciele władzy ustawodawczej, władzy wykonawczej i władzy sądowniczej, w którym dominują sędziowie. Konstytucja z 1997 r. ustanowiła, że organ ten składa się z 25 członków: Pierwszego Prezesa Sądu Najwyższego, Ministra Sprawiedliwości, Prezesa Naczelnego Sądu Administracyjnego, osoby powołanej przez Prezydenta Rzeczypospolitej, piętnastu członków wybranych spośród sędziów Sądu Najwyższego, sądów powszechnych, sądów administracyjnych i sądów wojskowych, czterech członków wybranych przez Sejm spośród posłów oraz dwóch członków wybranych przez Senat spośród senatorów (art. 187 ust. 1). Konstytucja nie stanowi zatem wprost, że sędziowie w składzie Krajowej Rady Sądownictwa powinni być wybierani przez sędziów. Przez Trybunał Konstytucyjny oraz większość przedstawicieli doktryny było to jednak wyprowadzane z zasady demokratycznego państwa prawnego, zasady trójpodziału władzy oraz zasady niezależności sądów i niezawisłości sędziów. Taka była też praktyka do 2017 r. Wówczas na podstawie wykładni językowej uznano jednak, że sędziowie w składzie Krajowej Rady Sądownictwa mogą być wybierani przez Sejm, co też uczyniono w 2018 r., skracając przy okazji kadencję dotychczasowych sędziów będących członkami tego organu. Rozwiązanie to jest krytykowane przez zdecydowaną większość środowiska prawniczego, w tym sędziowskiego. Zrodziło to pytanie, czy obecny skład Krajowej Rady Sądownictwa jest zgodny z Konstytucją. Autor w pełni podziela pogląd, że tak nie jest.
\end{abstract}

Słowa kluczowe: konstytucja, władza sądownicza, Krajowa Rada Sądownictwa.

\section{THE PROBLEM OF CONSTITUTIONALITY OF THE COMPOSITION OF THE CURRENT NATIONAL COUNCIL OF THE JUDICIARY IN POLAND}

\begin{abstract}
The National Council of the Judiciary was established in Poland in 1989 as a constitutional body. Her most important task is to safeguard the independence of the courts and the independence of judges. From the beginning, it is a mixed body composed of representatives of the legislative, executive and judicial powers dominated by judges. The 1997 Constitution established that this body consists of 25 members: the First President of the Supreme Court, the Minister of Justice, the President of the Supreme Administrative Court, a person appointed by the President of the Republic of Poland, fifteen members selected from among the Supreme Court judges, common courts, administrative courts and courts military members, four members elected by the Sejm from

* Uniwersytet Łódzki, Wydział Prawa i Administracji, Katedra Prawa Konstytucyjnego, kskotnicki@wpia.uni.lodz.pl.
\end{abstract}


among deputies and two members elected by the Senate from among senators (Article $187 \S 1$ ). Therefore, the Constitution does not explicitly state that judges in the composition of the National Council of the Judiciary should be elected by judges. However, by the Constitutional Tribunal and the majority of representatives of the doctrine, this was derived from the principle of a democratic state ruled by law, the principle of the separation of powers, and the principle of the independence of the courts and the independence of judges. This was also the practice until 2017. At the time, based on the linguistic interpretation, it was considered that the judges in the National Council of the Judiciary could be elected by the Sejm, which was also done in 2018, while shortening the term of office of the current judges who are members of this body. This solution is criticized by the vast majority of the legal community, including the judicial one. This raised the question of whether the current composition of the National Council of the Judiciary is compatible with the Constitution. The author fully shares the view that this is not the case.

Keywords: constitution, judiciary power, the National Council of the Judiciary.

W demokratycznych państwach prawnych, w których ustrój polityczny opiera się na zasadzie trójpodziału władzy, wielkie znaczenie przywiązuje się do niezależności sądów i niezawisłości sędziów. W tym celu poszukuje się wiele gwarantujących to instytucji. Jedną z nich są specjalne organy, które określane są ogólną nazwą „rada sądownictwa”. Ich tworzenie nie jest warunkiem sine qua non istnienia niezależnego sądownictwa i niezawisłości sędziowskiej, tym niemniej pod koniec XX w. pojawiły się one w wielu państwach europejskich, w tym zwłaszcza w krajach Europy Środkowej i Wschodniej - np. Polska - 1989 r., Węgry - 1991 r., Bułgaria - 1991 r., Chorwacja - 1993 r., Litwa - 1994 r., Ukraina -1998 r. (Godlewski 2019, 198).

Problem utworzenia w Polsce takiego organu został bardzo wyraźnie podniesiony przez opozycję w 1989 r. w trakcie obrad tzw. okrągłego stołu. Rada miała składać się z przedstawicieli władzy ustawodawczej, władzy wykonawczej i władzy sądowniczej. W konsekwencji w ustawie z dnia 7 kwietnia 1989 r. o zmianie Konstytucji Polskiej Rzeczypospolitej Ludowej (Dz. U., nr 19, poz. 101) ustanowiono m.in. nowe brzmienie art. 60 Konstytucji PRL, zgodnie z którym „sędziowie są powoływani przez Prezydenta, na wniosek Krajowej Rady Sądownictwa", której uprawnienia, skład i sposób działania określi ustawa. Była to ustawa z 20 grudnia 1989 r. o Krajowej Radzie Sądownictwa (Dz. U., nr 73, poz. 435).

Rada miała strzec niezawisłości sędziowskiej i niezależności sądów, rozpatrywać kandydatury na stanowiska sędziów i przedstawiać je Prezydentowi, rozpatrywać i rozstrzygać wnioski o przeniesienie sędziego na inne miejsce służbowe, wyrażać zgodę na dalsze zajmowanie stanowiska przez sędziego, który ukończył 65 lat, opiniować propozycje zmian ustroju sądów oraz wypowiadać się odnośnie do projektów aktów normatywnych dotyczących sądownictwa i w innych sprawach związanych z ich funkcjonowaniem (art. 2).

Zgodnie z art. 4 w skład Rady wchodzili pierwotnie: Pierwszy Prezes Sądu Najwyższego, Prezes Sądu Najwyższego kierujący pracami Izby Wojskowej Sądu Najwyższego, Prezes Naczelnego Sądu Administracyjnego, dwóch sędziów 
Sądu Najwyższego, sędzia Naczelnego Sądu Administracyjnego, dziewięciu sędziów sądów powszechnych, sędzia sądu wojskowego, czterech posłów, dwóch senatorów, osoba wskazana przez Prezydenta oraz Minister Sprawiedliwości. Tym samym można było wyróżnić trzy grupy członków: osoby wchodzące w jej skład z urzędu, wybierani sędziowie i osoby wybrane przez ciała polityczne. Zdecydowanie dominowali przy tym sędziowie (66\% składu), ustawa przesądzała również o tym, że są oni wybierani odpowiednio przez zgromadzenia ogólne sędziów Sądu Najwyższego, Naczelnego Sądu Administracyjnego, sądów wojewódzkich (dwóch sędziów), w których uczestniczyli delegaci wybierani przez sądy rejonowe oraz zgromadzenia sądów wojskowych (wybierały jednego sędziego). Utworzenie w 1990 r. sądów apelacyjnych spowodowało rozszerzenie składu Rady o kolejnych dwóch sędziów sądów apelacyjnych wybieranych przez zgromadzenia ogólne sędziów tych sądów, co zwiększyło ogólną liczbę członków tego organu do 26 , zaś sędziowie stanowili w nim co najmniej $70 \%$, gdyż nie było przeszkód, aby sędzią był również np. przedstawiciel Prezydenta. Jak zatem widać, skład Rady był zróżnicowany, określany w literaturze przedmiotu jako mieszany (Sarnecki 2008, 201; Garlicki 2005) lub złożony (Winczorek 2000, 242), ale zdecydowanie dominowali w nim sędziowie wybierani przez sędziów (Sarnecki 2008, 186-187). Nie może budzić wątpliwości, że miało to na celu doprowadzenie do prawdziwego odrodzenia władzy sądowniczej i wymiaru sprawiedliwości.

Z uwagi na przedmiot opracowania nie odnoszę się szerzej do kwestii sporów o ustrojowy charakter KRS, jak i jego pozycję ustrojową. Jest to dogłębnie omówione w literaturze przedmiotu (Tuleja 2010, Niezgódka-Medek 2019), odnosi się do tego orzecznictwo Trybunału Konstytucyjnego ${ }^{1}$ i Sądu Najwyższego ${ }^{2}$. KRS nie można zakwalifikować do żadnej z trzech władz, jest to od samego początku samodzielny konstytucyjny organ państwa powiązany z władzą sądowniczą, choć nie stanowiący jej elementu (Godlewski 2019, 201). Jej niewątpliwy związek z samorządem sędziowskim (wyrażający się w zgromadzeniach ogólnych sędziów odpowiednich sądów) prowadzi nawet niektórych autorów do wniosku, że stanowi ona „zwieńczenie struktury samorządu sędziowskiego” (Sarnecki 2008, 200), co w moim przekonaniu jest jednak tezą idącą zbyt daleko.

Mała Konstytucja z 1992 r. utrzymała instytucję Krajowej Rady Sądownictwa w ten sposób, że nadal ustanawiała, że sędziowie są powoływani przez Prezydenta na jej wniosek (art. 42). Z racji regulacji wyłącznie władzy ustawodawczej i wykonawczej oraz samorządu terytorialnego nie odnosiła się szerzej zarówno do władzy sądowniczej, jak i samej Rady. Znaczenie tego organu niewątpliwie umocniła natomiast Konstytucja z 2 kwietnia 1997 r. Nastąpiło to przede wszystkim poprzez

${ }^{1}$ Zob. wyroki TK: z 18 lutego 2004 r., z 29 listopada 2007 r. (w sprawie SK 43/06), z 16 kwietnia 2008 r. (w sprawie K 40/07), z 27 maja 2008 r. (w sprawie SK 57/06), a w szczególności wyrok z 19 listopada 2009 r. (w sprawie K 62/07, OTK-A 2009/10, poz. 149).

${ }^{2}$ Zob. np. uchwała Sądu Najwyższego z dnia 23 lipca 1992 r. III AZP 9/92. 
przyznanie jej prawa inicjowania postępowania przed Trybunałem Konstytucyjnym w sprawie zgodności z Konstytucją RP aktów normatywnych w zakresie, w jakim dotyczą one niezależności sądów i niezawisłości sędziów (art. 186 ust. 2, art. 191 ust. 1 pkt 2). Rada uzyskała również szereg innych uprawnień, których tutaj z uwagi na przedmiot opracowania nie wymieniam. Konstytucja zmniejszyła również skład Rady do 25 osób, pomijając w nim - w porównaniu ze stanem wcześniejszym - Prezesa Izby Wojskowej ${ }^{3}$.

Konsekwencją wejścia w życie nowej Konstytucji było uchwalenia ustawy z 27 lipca 2001 r. o Krajowej Radzie Sądownictwa (Dz. U. nr 100, poz. 1082 ze zm.; t.j. Dz. U. z 2010 r., nr 11, poz. 67). W zakresie sposobu wyboru sędziów w skład Rady nie wprowadzała ona zmian. Inne jej postanowienia odnosiły się do kwestii proceduralnych związanych z funkcjonowaniem KRS. W szczególności kontrowersyjny okazał się przepis, w myśl którego kwestia ta miała zostać uregulowana rozporządzeniem Prezydenta RP (art. 12 ust. 6), co też zostało uczynione ${ }^{4}$. Zostało to jednak uznane za niekonstytucyjne, a Trybunał Konstytucyjny wskazał, że jest to materia ustawowa ${ }^{5}$. Między innymi to sprawiło, że w dniu 12 maja 2011 r. została uchwalona kolejna ustawa o Krajowej Radzie Sądownictwa (Dz. U. nr 126, poz. 714). Poza uregulowaniem kwestii proceduralnych, znalazły się w niej również inne sprawy. W zakresie sposobu wyboru sędziów wzmocniono wpływ sędziów sądów wyższych instancji (Pęk 2013, 97). Ustawa, co do zasady, utrzymała złożony sposób dokonywania tego w wyborach pośrednich przez organy samorządu sędziowskiego, a więc zebrania przedstawicieli zgromadzeń ogólnych sędziów okręgu, zebrania przedstawicieli zebrań sądów apelacyjnych, a także przedstawicieli zgromadzeń ogólnych wojewódzkich sądów administracyjnych obradujących wspólnie ze Zgromadzeniem Ogólnym Sędziów NSA; bezpośrednio swoich przedstawicieli wybierali jedynie sędziowie SN, NSA i sądów wojskowych.

Pozakonstytucjne i antykonstytucyjne zmiany ustroju Polski, jakie mają miejsce po wyborach parlamentarnych z 2015 r., przede wszystkim dotyczą władzy sądowniczej. Dotyczy to zarówno Trybunału Konstytucyjnego ${ }^{6}$, Sądu Najwyższego $^{7}$, jak i sądów powszechnych ${ }^{8}$. W 2017 r. zmiany dosięgły również Krajowej

\footnotetext{
${ }^{3}$ Izba Wojskowa została zlikwidowana w Sądzie Najwyższym z dniem 4 kwietnia 2018 r.

${ }^{4}$ Było to rozporządzenie Prezydenta RP z 13 listopada 2011 r. w sprawie szczegółowego trybu działania Krajowej Rady Sądownictwa oraz postępowania przed Radą (Dz. U., nr 219, poz. 1623).

${ }^{5}$ Szerzej zob. Niezgódka-Medek 2019, 101.

${ }^{6}$ W składzie Trybunału zasiadają trzej sędziowie, których wybór przez Sejm po 2015 r. jest kwestionowany przez środowiska prawnicze.

${ }^{7}$ Utworzono dwie nowe Izby, do których powołano sędziów, w tym również osoby, które wcześniej nie piastowały stanowiska sędziego, jak i próbowano przenieść w stan spoczynku znaczną część dotychczasowych sędziów SN z uwagi na ukończenie przez nich 65 lat (wycofano się z tego w dużej mierze pod wpływem opinii międzynarodowej).

${ }^{8}$ Lekceważąc orzecznictwo Trybunału Konstytucyjnego zmieniono sposób powoływania i odwoływania prezesów i wiceprezesów sądów powszechnych uzależniając to wyłącznie od decyzji ministra sprawiedliwości i pozbawiając wpływu samorząd sędziowski.
} 
Rady Sądownictwa. Wprawdzie w przypadku ustawy z 12 lipca 2017 r. o zmianie ustawy o Krajowej Radzie Sądownictwa oraz niektórych innych ustaw Prezydent RP odmówił jej podpisania, to jednak czyniąc to wyraźnie podniósł, że dokonanie zmian jest konieczne (Rakowska-Trela 2019). Z jego inicjatywy doszło też do uchwalenia ustawy z 8 grudnia 2017 r. o zmianie ustawy o Krajowej Radzie Sądownictwa oraz niektórych innych ustaw (Dz. U. z 2018 r., poz. 3). Jednym z najbardziej kontrowersyjnych rozwiązań jest ustanowienie dokonywania wyboru sędziów do KRS przez Sejm, a nie, jak miało to miejsce wcześniej, przez samorząd sędziowski.

Według obowiązującego stanu prawnego Sejm dokonuje wyboru sędziów do Krajowej Rady Sądownictwa spośród kandydatów zgłoszonych przez grupę co najmniej 2000 obywateli, którzy ukończyli 18 lat oraz mają pełną zdolność do czynności prawnych i korzystają z pełni praw publicznych lub grupę co najmniej 25 sędziów, z wyjątkiem sędziów w stanie spoczynku. Zgłoszenia kierowane są do Marszałka Sejmu, który w przypadku wątpliwości odnośnie do prawidłowości podpisów przez obywateli może zwrócić się do Państwowej Komisji Wyborczej z wnioskiem o zbadanie, czy złożono wymaganą liczbę podpisów. Jeżeli Marszałek odmówi przyjęcia zgłoszenia z uwagi na zbyt małą liczbę podpisów, istnieje możliwość zaskarżenia tej decyzji w ciągu 3 dni do Sądu Najwyższego. Status sędziego zgłaszającego kandydata do KRS potwierdza natomiast minister sprawiedliwości. Zweryfikowane pozytywnie kandydatury sędziów do Rady są następnie przekazywane posłom i podawane do publicznej wiadomości. Spośród tych kandydatów każdy klub poselski w ciągu 7 dni może wskazać nie więcej niż 9 swoich kandydatów na członków KRS (jest to wybór kandydatów spośród kandydatów). Gdyby łączna liczba kandydatów zgłoszonych przez wszystkie kluby była mniejsza niż 15, brakującą liczbę kandydatów spośród kandydatów wskazanych przez obywateli bądź sędziów wskazuje Prezydium Sejmu. Następnie właściwa komisja sejmowa (obecnie jest to Komisja Sprawiedliwości) ustala spośród tych kandydatów listę 15 kandydatów na członków Rady (jest to zatem kolejne sito selekcji kandydatów), przy czym na tej liście musi być co najmniej jeden kandydat prawidłowo wskazany przez każdy klub poselski. Ostatnim etapem procedury wyboru sędziów do KRS jest głosowanie w Sejmie. Głosowanie odbywa się łącznie na listę kandydatów zgłoszonych przez komisję. Sejm podejmuje decyzję większością $3 / 5$ głosów w obecności co najmniej połowy ustawowej liczby posłów. Jeżeli taka większość nie zostanie osiągnięta, odbywa się ponowne głosowanie, w którym dla wyboru wymagana jest bezwzględna większość głosów w obecności co najmniej połowy ustawowej liczby posłów. Gdyby również to głosowanie nie doprowadziło do wyboru 15 sędziów do składu Rady, wybór przeprowadzany jest zgodnie z przepisami dotyczącymi wskazania kandydatów przez kluby poselskie.

Należy postawić pytanie, czy ustanowienie takiego sposobu wyboru sędziów w skład Krajowej Rady Sądownictwo jest zgodne z Konstytucją. 
W przeszłości w literaturze przedmiotu dopuszczano taką ewentualność, należy jednak wyraźnie stwierdzić, że było to zdania odosobnione. Pogląd taki prezentowała Katarzyna Kaczmarczyk-Kłak. Podnosiła ona, że Konstytucja w art. 187 ust. 1 pkt 2, stanowiąc o wyborze sędziów „spośród sędziów”, nie wskazuje, kto ma tego wyboru dokonać; jednocześnie podkreślała, że Konstytucja wyraźnie przesądza o tym w art. 187 ust. 1 pkt 3, że Sejm wybiera w skład Rady czterech posłów, zaś Senat wybiera dwóch senatorów. Prowadziło ją to do wniosku, że Konstytucja pozostawia ustawodawcy decyzję o tym, kto ma wybierać sędziów w skład KRS. Za tezą tą przemawiać ma również fakt, że Konstytucja w art. 187 ust. 4 stanowi, że ustawa ma określić „sposób wyboru jej (tj. Krajowej Rady Sądownictwa) członków”, co w przypadku słowa „sposób” dopuszcza uznanie, że może to być również określenie organu, który ma to czynić. Pogląd ten pozostaje w sprzeczności ze stanowiskiem Trybunału Konstytucyjnego wyrażonym w wyroku z 18 lipca 2007 r w sprawie K 25/07, w którym wprost stwierdził, że art. 187 ust. 1 pkt 2 Konstytucji „wyraźnie określa, że członkami KRS mogą być sędziowie, wybierani przez sędziów". Katarzyna Kaczmarczyk-Kłak uznała jednak, że

stanowisko to nie znajduje oparcia w wyraźnym brzmieniu art. 187 ust. 1 pkt 2 Konstytucji, zwłaszcza gdy zestawi się ten przepis z pkt 3 tego samego artykułu, jak również, gdy dostrzeże się, że tam, gdzie Konstytucja określa organ podejmujący daną decyzję, czyni to zawsze wyraźnie (np. art. 194 ust. 2; art. 199 ust. 1; art. 205 ust. 1 czy też art. 209 ust. 1); zgodnie z zasadą legalizmu (art. 7 Konstytucji) kompetencji do podjęcia decyzji nie można domniemywać; przywołać należy tu stanowisko zaprezentowane przez Sąd Najwyższy w postanowieniu z dnia 15 marca 2011 r., III KRS 1/11, OSNP 2012, nr 9-10, poz. 131, że w regulacji konstytucyjnej (art. 187 ust. 1 pkt 2 Konstytucji), nie określono wyłącznie prawa sędziów do wyboru piętnastu członków Krajowej Rady Sądownictwa, ale stanowi się, że ci członkowie wybierani są „spośród sędziów Sądu Najwyższego i sądów powszechnych, sądów administracyjnych i sądów wojskowych";

zdaniem Sądu Najwyższego wynikają stąd wyraźne wskazówki ustawodawcy konstytucyjnego, które uformowany konstytucyjnie skład Krajowej Rady Sądownictwa wiąże z udziałem sędziów („spośród sędziów”) i będących przedstawicielami Sądu Najwyższego i innych sądów, nie przesądzono jednak, że owych sędziów bezwzględnie wybierać muszą sami sędziowie (Kaczmarczyk-Kłak 2017, 438-439).

W literaturze przedmiotu niewątpliwie dominował jednak pogląd, zgodnie z którym sędziów w skład KRS powinni wybierać sędziowie. Przykładowo, Leszek Garlicki już przed laty, akcentując dominację sędziów w składzie KRS, podkreślał, że „są oni wybierani przez swoje środowisko”, co jest „logicznym następstwem powierzenia Radzie zadania ochrony niezależności sądów i niezawisłości sędziów, tym bardziej, że pozostałe władze zachowują inne środki oddziaływania na skład i funkcjonowanie sądownictwa" (Garlicki 2005). Podkreślał, że sędziowie muszą zostać „wybrani”, Konstytucja nie przesądza jednak, czy wybór ma być 
powiązany z istniejącym systemem samorządu sędziowskiego, czy nawiązywać do typowych procedur wyborczych, opartych na zasadzie powszechności, równości i bezpośredniości (Garlicki 2005). W tym samym duchu wypowiadał się również Bogusław Banaszak, który pisał: „Konstytucja nie ustala ani zasad, ani trybu, ani też proporcji, w jakiej poszczególne sądy wymienione w art. 187 ust. 1 pkt 2 mają dokonać wyboru 15 członków KRS, zaznacza tylko, że wybrani muszą być spośród sędziów, a więc, że muszą sami być sędziami” (Banaszak 2009).

Ustanawiając nowy sposób wyboru sędziów w skład KRS, przywołano jednak całkiem niedawny wyrok Trybunału Konstytucyjnego z 20 czerwca 2017 r. w sprawie K 5/17 (OTK-A 2017, poz. 48), wydany z udziałem sędziów, których wybór jest - jak już podkreślałem - kwestionowany. Stwierdzono w nim:

Trybunał Konstytucyjny w obecnym składzie nie zgadza się ze stanowiskiem zajętym w wyroku o sygn. K 25/07, że Konstytucja określa, iż członkami KRS mogą być sędziowie wybierani przez sędziów. Art. 187 ust. 1 pkt 2 Konstytucji stanowi jedynie, że osoby te są wybierane spośród sędziów. Ustrojodawca nie wskazał jednak, kto ma wybierać tych sędziów. Zatem z Konstytucji wynika, kto może być wybrany członkiem KRS, ale nie jest określone, jak wybrać sędziów członków KRS do tej Rady. Te kwestie zostały przekazane do uregulowania w ustawie.

Dla obecnej władzy jest to stanowisko wiążące, pozwala bowiem uznać sposób wyboru sędziów do KRS za zgodny z Konstytucją.

W literaturze przedmiotu ustanowione rozwiązanie jest ostro krytykowane. Głosy wskazujące na niekonstytucyjność proponowanego rozwiązania pojawiły się zaraz po pierwszej próbie nowelizacji ustawy o KRS w 2017 r. (Piotrowski 2017, 14-15). Znacznie więcej pojawiło się ich jednak po wejście w życie wprowadzonych zmian.

Leszek Garlicki ostro krytykuje nowelizację z 2017 r. Podkreśla, że tym samym o składzie KRS decyduje obecnie większość parlamentarna, ,a tym samym władza sądownicza została pozbawiona autonomicznej kompetencji do wyznaczania swoich reprezentantów". I dalej:

Rozwiązania tego nie da się pogodzić ani z zasadą podziału i równowagi władz (art. 10), ani z zasadą niezależności sądów od innych władz (art. 173). W polskim modelu relacji między władzami Krajowa Rada odgrywać ma rolę szczególnego zwornika, chroniącego sądownictwo przed bezpośrednimi ingerencjami parlamentu bądź władzy wykonawczej. Konieczną przesłanką należytego wypełniania tej roli jest niezależność Rady od tych władz. Trzeba przecież pamiętać, że wiele kompetencji Rady dotyczy spraw personalnych sądownictwa, a obecne rozwiązania pozwalają władzom politycznym na takie uformowanie składu Rady, które - w szczególności - pozwala im na pośrednie kontrolowanie procesu nominacji sędziowskich (Garlicki 2018, 39).

Podobne stanowisko zajmuje Andrzej Szmyt, którego uwagi odnosiły się wprawdzie do projektu ustawy zawetowanej przez Prezydenta, jednak w pełni zachowały aktualność po wejściu w życie nowych rozwiązań. Podziela on pogląd, że Konstytucja nie przesądza wprost o tym, kto ma wybierać sędziów do KRS, ale jednocześnie podkreśla, że Konstytucja w art. 187 ust. 1 pkt 3 explicite przesądza 
o tym, że do KRS posłowie wybierani są przez Sejm, a senatorowie przez Senat. Jego zdaniem dowodzi to, że wolą ustrojodawcy nie było, aby parlament wybierał jeszcze 15 sędziów. Pisze dlatego:

W przepisie Konstytucji widoczne jest założenie, że parlament ma mieć „swój” wpływ na Krajową Radę Sądownictwa poprzez posłów i senatorów, a nie poprzez jeszcze inne kategorie członków Rady. Gdyby miało być inaczej, to Konstytucja inaczej i wyraźnie ukształtowałaby kompetencję Sejmu.

Uznał dlatego, że rozwiązanie, w którym parlament obsadza 21 z 25 członków Rady przekreśla konstytucyjne założenie o mieszanym charakterze tego organu. Podziela też pogląd, że godzi to w art. 187 ust. 1 Konstytucji, zasadę podziału i równoważenia władz (art. 10) oraz niezależność i odrębność władzy sądowniczej - art. 173 i art. 186 ust. 1 (Szmyt 2019, 125). Podobne zdanie prezentuje również Krzysztof Grajewski (2017, 104-105).

Niezwykle krytycznie o przywołanym wyroku TK z 2017 r. oraz dokonanej nowelizacji ustawy o KRS wypowiedziała się również Anna Rakowska-Trela. W obszernym wywodzie, w którym podkreśla znaczenie mieszanego charakteru składu dla Rady jako organu stojącego na straży niezawisłości sądów i niezależności sędziów, konkluduje, że przyjęte rozwiązanie

unicestwia $[\ldots]$ wymagane konstytucyjnie proporcje, przyznając nieusprawiedliwioną i niedopuszczalną przewagę władzy ustawodawczej (a ściślej Sejmowi). [...] prowadzi do bowiem do zagrożenia wartości chronionych przez KRS, a przez to istoty i ustrojowej funkcji tego organu, w konsekwencji zaś prawa do sądu oraz wolności i praw człowieka. Oddanie prawa wyboru ponad $3 / 4$ składu KRS Sejmowi (a licząc łącznie z członkami wybieranymi przez Senat - 84\% składu) pozostaje w sprzeczności z trójpodziałem władzy, odrębnością i niezależnością władzy sądowniczej i raczej przypomina określenie składu KRS w oparciu o zasadę dominacji władzy ustawodawczej, w szczególności Sejmu nad władzą sądowniczą, nie zaś o zasadę trójpodziału władzy (Rakowska-Trela 2017, 112-113).

W pełni podzielam wszystkie przywołane krytyczne oceny nowelizacji ustawy o Krajowej Radzie Sądownictwa dokonanej w 2017 r. W moim przekonaniu argumentacja przywoływana przez jej zwolenników, a w szczególności budowanie podstawy dla wprowadzonej zmiany w oparciu o stwierdzenie, że Konstytucja w art. 187 ust. 1 pkt 2 nie przesądza, kto ma wybierać sędziów w skład Rady, jest akademickim przykładem błędnego poprzestania w analizie normy prawnej wyłącznie na wykładni językowej, bez uwzględnienia całości regulacji aktu prawnego, w którym się ona znajduje, w tym w szczególności zasad, na których zbudowany jest cały akt prawny. Przepis wymaga innej wykładni nawet wówczas, gdy jest jasny w wyniku zastosowania wykładni językowej. Analizując przepis, nie można pomijać treści innych przepisów. Nie od rzeczy wydaje się również sięgnięcie do wykładni historycznej, czego nie czynią jednak nawet przeciwnicy zmiany wprowadzonej nowelizacją z $2017 \mathrm{r}$. Odmienne rozumowanie dowodzi popełniania elementarnych błędów w prawniczej analizie znaczenia tekstu interpretowanej normy. 
Powyższy wywód dowodzi zasadności pytania o konstytucyjność obecnej regulacji prawnej składu Krajowej Rady Sądownictwa, a odpowiedź może być tylko jedna.

Ale nie jest to wątpliwość jedyna. Nowelizacja ustawy o KRS z 2017 r. wprowadziła również wspólną czteroletnią kadencję dla wszystkich sędziów wybieranych w skład Rady. Niekonstytucyjność przyjętego rozwiązania wynika z faktu, iż Konstytucja w art. 187 ust. 3 stanowi o kadencji wybieranych sędziów, nie zaś o kadencji KRS. Warto przywołać też słowa Leszka Garlickiego, który przed laty pisał: „zasada wyboru większości członków KRS na czteroletnią kadencję nie nadaje samej Radzie charakteru organu kadencyjnego [...] Tym samym, kadencja wybieranych członków Rady powinna być liczona indywidualnie" (2005), Rada, w myśl postanowień Konstytucji, jest organem działającym w permanencji, dlatego też i z tego punktu widzenia można mieć wątpliwości odnośnie do konstytucyjności rozwiązania przyjętego w nowelizacji z $2017 \mathrm{r}$.

Nie ulega również wątpliwości, że ewidentnym naruszeniem postanowień Konstytucji było wygaszenie z chwilą wejścia w życie ustawy z 2017 r. nowelizującej ustawę o KRS kadencji wszystkich dotychczasowych 15 sędziów wybranych przez samorząd sędziowski. Zostali oni wybrani na konstytucyjną czteroletnią kadencję (art. 187 ust. 3), stąd nie jest możliwe ich wcześniejsze odwołanie ${ }^{9}$. Argumentacja, iż skrócenie kadencji jest niezbędne z uwagi na konieczność wprowadzenia w życie przyjętych nowych rozwiązań, nie przekonuje, gdyż postanowienia Konstytucji odnośnie do kadencji sędziów zasiadających w KRS są jednoznaczne. Nie dziwi dlatego, że dwaj sędziowie będący dotychczas członkami Rady (Jan Grzęda i Waldemar Żurek, który był rzecznikiem prasowym KRS) złożyli skargi do Europejskiego Trybunału Praw Człowieka (ETPC). Sędzia J. Grzęda zarzucił naruszenie art. $6 \S 1$ oraz art. 13 Europejskiej Konwencji Praw Człowieka gwarantujących prawo do rzetelnego procesu sądowego oraz prawo do skutecznego środka odwoławczego. ETPC uznał już, że rozpatrzy tę sprawę (skarga nr 43572/18) ${ }^{10}$. Na temat składu obecnej Krajowej Rady Sądownictwa wypowie się również Trybunał Sprawiedliwości Unii Europejskiej (TSUE). Jest to następstwo wniosków Sądu Najwyższego o wydanie orzeczenia w trybie prejudycjalnym. Już jednak Rzecznik Generalny TSUE w wydanej opinii stwierdził, że obecna Rada nie daje rękojmi niezależności od władzy ustawodawczej i wykonawczej.

Odrębną kwestią, którą jedynie sygnalizuję, jest problem ujawnienia nazwisk sędziów, którzy zgłosili kandydatów na sędziów do Krajowej Rady Sądownictwa. Marszałek Sejmu nie ujawnił ich, jako że art. 11c znowelizowanej ustawy

${ }^{9}$ Szerzej zob. Rakowska-Trela 2017, 119-121.

${ }^{10} \mathrm{~W}$ skardze tej, jak i pytaniach postawionych polskiemu rządowi przez ETPC widać nawiązanie do znanej sprawy Andrása Baki, który w 2011 r. przestał być prezesem węgierskiego Sądu Najwyższego w następstwie zmian w węgierskim prawie, gdy zgodnie z Konstytucją miał ją pełnić do czerwca 2015 r. Trybunał w 2014 r., jak i później Wielka Izba Trybunału w 2016 r. w następstwie zaskarżenia tego wyroku przez rząd węgierski uznały m.in. naruszenie art. 6 EKPC. 
o KRS nakazuje mu niezwłoczne przekazanie kandydatur posłom oraz podanie ich do publicznej wiadomości, jednak bez załączników. Należy jednak pamiętać, że obowiązują jeszcze inne ustawy, w tym przede wszystkim ustawa z 6 września 2001 r. o dostępie do informacji publicznej (t.j. Dz. U. z 2019 r., poz. 1429). Problem ten stał się przedmiotem wyroków najpierw Wojewódzkiego Sądu Administracyjnego w Warszawie, a następnie Naczelnego Sądu Administracyjnego. NSA w wyroku z 28 czerwca 2019 r. stwierdził, że „objęta wnioskiem o udostępnienie informacja w postaci załączników do zgłoszeń kandydatów na członków Krajowej Rady Sądownictwa w zakresie wykazów obywateli oraz wykazów sędziów popierających zgłoszenia mieści się w pojęciu informacji publicznej”. Uznał również, że ograniczenie prawa do informacji publicznej z powołaniem się na przepis art. 5 ust. 2 u.d.i.p. w stosunku do wykazu sędziów popierających zgłoszenia kandydatów do KRS nie może mieć zastosowania, bowiem informacja ta ma związek z wykonywaniem przez sędziów funkcji publicznych. Wskazał ponadto, że „udostępnienie wykazu sędziów popierających zgłoszenia kandydatów do KRS powinno nastąpić po uprzedniej anonimizacji numeru ewidencyjnego PESEL sędziego, który nie jest związany z pełnioną funkcją publiczną, a zatem nie powinien podlegać udostępnieniu" (sygn. akt I OSK 4282/18). Pomimo tego wyroku nazwiska sędziów, którzy zgłosili sędziów-kandydatów do KRS, nie zostały ujawnione. Stało się tak, gdyż wybrany w tym roku przez rządzącą większość i sprawujący urząd od 16 maja 2019 r. Prezes Urzędu Ochrony Danych Osobowych wydał 29 lipca 2019 r. decyzję, aby nie były one ujawniane. Powołał się na art. 70 ust. 1 ustawy z dnia 10 maja 2018 r. o ochronie danych osobowych (Dz. U. z 2018 r., poz. 1000, 1669; z 2019 r., poz. 730), zgodnie z którym,

[J]eżeli w toku postępowania zostanie uprawdopodobnione, że przetwarzanie danych osobowych narusza przepisy o ochronie danych osobowych, a dalsze ich przetwarzanie może spowodować poważne i trudne do usunięcia skutki, Prezes Urzędu, w celu zapobieżenia tym skutkom, może, w drodze postanowienia, zobowiązać podmiot, któremu jest zarzucane naruszenie przepisów o ochronie danych osobowych, do ograniczenia przetwarzania danych osobowych, wskazując dopuszczalny zakres tego przetwarzania.

Decyzje te, moim zdaniem w pełni zasadnie, zostały zaskarżone przez Rzecznika Praw Obywatelskich do Wojewódzkiego Sądu Administracyjnego. Rzecznik zarzucił, że Prezes UODO w precedensowy sposób przyznał sobie prawo do kontrolowania prawomocnych orzeczeń sądu. Skorzystał także z przysługującego mu prawa i przystąpił do postępowań toczących się przed Prezesem UOD, argumentując, że w tym przypadku rzecz idzie zarówno o realizację konstytucyjnego prawa do uzyskiwania informacji o działalności organów władzy publicznej oraz osób pełniących funkcje publiczne, ale również o stabilność systemu prawnego w Polsce i wykonywanie prawomocnych orzeczeń sądów. Jak na razie nazwiska sędziów, którzy zgłosili sędziów kandydatów do KRS, nie zostały jednak ujawnione. 
Spór o skład obecnej Krajowej Rady Sądownictwa, nazywanej przez wielu neo-KRS, nie dotyczy tylko tego, czy sędziowie, którzy w niej zasiadają, mogą być wybierani przez polityków, a nie przez samych sędziów. Jest to spór o to, czy mają znaczenie prawne decyzje, które podejmuje ten organ. W szczególności jest to pytanie, czy powinny pełnić funkcje sędziowskie osoby, które organ ten rekomendował Prezydentowi RP do powołania na te stanowiska, a w konsekwencji, jaką moc mają wydawane przez nie wyroki. Jest to kwestia niezwykle złożona, a jej rozwiązanie - w moim przekonaniu - możliwe jest tylko przez podjęcie stosownych decyzji politycznych. Jestem daleki od kwestionowania tych wyroków, w przypadku sędziów powołanych w ostatnim czasie, uważam jednak, że powinni oni poddać się ponownej ocenie przez Krajową Radę Sądownictwa w składzie, który nie będzie budzić wątpliwości.

Wskazane problemy skłaniają również do refleksji nad mieszanym składem KRS. Należy przypomnieć, że Paweł Sarnecki już przed laty podnosił, że konstytucyjne cele funkcjonowania Rady nie uzasadniają takiego rozwiązania, nakazują również zastanowić się, czy osoby, które nie są sędziami, rzeczywiście rozumieją specyfikę trzeciej władzy.

Jeśli czterech posłów i dwu senatorów miałoby być „łącznikami” KRS (i w ogóle judykatywy) z legislatywą, to nie bardzo widać, jak miałoby to być realizowane. Tego rodzaju zespół nie posiada ani prawa inicjatywy ustawodawczej, ani też zagwarantowanej formalnie obecności w odpowiednich resortowo komisjach Sejmu czy Senatu. Zwiększenie wpływu na ustawodawstwo znacznie łatwiej można osiągnąć, przyznając jej prawo inicjatywy ustawodawczej w analogicznym zakresie do prawa skargi do TK niż utrzymywanie tych osób w składzie KRS (gdzie stanowią ponad 20\% składu). Wydaje się, że łatwiej im odgrywać rolę eksponenta legislatywy i egzekutywy (zwłaszcza jeśli idzie o Ministra Sprawiedliwości) w KRS, niż odwrotnie. Również „osoba powołana przez Prezydenta RP” nie posiada żadnego oficjalnego stanowiska np. w Kancelarii tego urzędu, nie jest też oficjalnie powołana do referowania spraw, z którymi KRS występuje wobec głowy państwa (ani też odwrotnie) i trudno odpowiedzieć, w jaki szczególny sposób miałaby przyczyniać się do realizacji funkcji KRS (2019).

Rozważania te wydają się najlepszym podsumowaniem tego opracowania.

\section{BIBLIOGRAFIA}

Banaszak, Bogusław. 2009. W Konstytucja RP. Komentarz, art. 187, Nb 3. Warszawa: Wydawnictwo C.H. Beck.

Garlicki, Lech. 2005. „Uwagi 3, 6 i 8 do art. 187”. W Lech Garlicki (red.). Konstytucja Rzeczypospolitej Polskiej. Komentarz. T. IV. Warszawa: Wydawnictwo Sejmowe.

Garlicki, Lech. 2018. Polskie prawo konstytucyjne. Zarys wykładu. Wyd. 5. Warszawa: Wolters Kluwer.

Godlewski, Mariusz. 2019. „Krajowa Rada Sądownictwa”. W Maria Kruk, Marcin Olszówka, Mariusz Godlewski, Mikołaj Jarosz, Marzena Laskowska, Jacek Zaleśny (red.). Ochrona praw $i$ wolności. System instytucjonalny w Rzeczypospolitej Polskiej, 197-208. Warszawa: Difin.

Grajewski, Krzysztof. 2017. „Zmiany statusu prawnego Krajowej Rady Sądownictwa”. W Zbigniew Witkowski, Jiri Jirásek, Krzysztof Skotnicki, Maciej Serowaniec (red.). Współczesne 
problemy sadownictwa w Republice Czeskiej i w Rzeczypospolitej Polskiej, 91-122. Torun: Wydawnictwo Naukowe Uniwersytetu Mikołaja Kopernika.

Kaczmarczyk-Kłak, Katarzyna. 2017. „Krajowa Rada Sądownictwa - charakter prawny, skład osobowy oraz struktura wewnętrzna". W Jerzy Posłuszny, Wiesław Skrzydło, Krzysztof Eckhardt (red.). Ustrój polityczny Rzeczypospolitej Polskiej, 422-448. Rzeszów: WSPiA Rzeszowskiej Szkoły Wyższej.

Niezgódka-Medek, Małgorzata. 2019. „Krajowa Rada Sądownictwa - jako gwarant niezależności sądów i niezawisłości sędziów do czasu wprowadzenia zmian na przełomie 2017 i 2018 r." W Łukasz Bojarski, Krzysztof Grajewski, Jan Kremer, Gabriela Ott, Waldemar Żurek (red.). Konstytucja - Praworządność - Władza sądownicza. Aktualne problemy trzeciej władzy w Polsce. 93-106. Warszawa: Wolters Kluwer.

Pęk, Ryszard. 2013. W Antoni Górski, Małgorzata Niezgódka-Medek (red.), Krajowa Rada Sadownictwa. Komentarz, Warszawa: Wolters Kluwer.

Piotrowski, Ryszard. 2017. „Konstytucyjne granice reformowania sądownictwa”. Krajowa Rada Sadownictwa 2: 5-29.

Rakowska-Trela, Anna. 2019. „Krajowa Rada Sądownictwa po wejściu w życie nowelizacji z 8.12. 2017 r. - organ nadal konstytucyjny czy pozakonstytucyjny?” W Łukasz Bojarski, Krzysztof Grajewski, Jan Kremer, Gabriela Ott, Waldemar Żurek (red.). Konstytucja - Praworządność - Władza sadownicza. Aktualne problemy trzeciej władzy w Polsce. 107-122. Warszawa: Wolters Kluwer.

Sarnecki, Paweł. 2008., „Krajowa Rada Sądownictwa”. W Andrzej Szmyt (red.). Trzecia władza - sady i trybunaty w Polsce. 185-203. Gdańsk: Wydawnictwo Uniwersytetu Gdańskiego.

Szmyt, Andrzej. 2019. „Kilka uwag w sprawie nowelizacji ustawy o krajowej radzie sądownictwa w Polsce". W Alena Krunková (red.), Organizácia súdnej moci v Pol’skej republike, Českej republike a Slovenskej republike (ústavné východiská a ich presadzovanie v ústavnopolitickej praxi). Zborník príspevkov z medzinárodnej vedeckej konferencie Organizácia súdnej moci v Pol'skej republike, Českej republike a Slovenskej republike (ústavné východiská a ich presadzovanie v ústavno-politickej praxi) konanej v dňoch 16.-18. mája 2018 v Košiciach. 120-131. Košice: Vydavatel'stvo ŠafárikPress UPJŠ v Košiciach.

Tuleja, Piotr. 2010. „Konstytucyjny status Krajowej Rady Sądownictwa”. W Piotr Tuleja (red.). Krajowa Rada Sadownictwa. XX-lecie działalności. 61-90. Toruń-Warszawa: Towarzystwo Naukowe Organizacji i Kierownictwa „Dom Organizatora”

Winczorek Piotr. 2000. Komentarz do Konstytucji Rzeczypospolitej Polskiej z dnia 2 kwietnia 1997 r., Warszawa: Liber.

\section{AKTY PRAWNE}

Konstytucja z dnia 2 kwietnia 1997 r., Dz. U. z 1997 r., nr 78, poz. 483; z 2001 r., nr 28, poz. 319; z 2006 r., nr 200, poz. 1471; z 2009 r., nr 114, poz. 946.

Ustawa z dnia 7 kwietnia 1989 r. o zmianie Konstytucji Polskiej Rzeczypospolitej Ludowej, Dz. U., nr 19, poz. 101.

Ustawa z dnia 20 grudnia 1989 r. o Krajowej Radzie Sądownictwa, Dz. U., nr 73, poz. 435.

Ustawa z dnia 27 lipca 2001 r. o Krajowej Radzie Sądownictwa, Dz. U., nr 100, poz. 1082 ze zm.; t.j. Dz. U. z 2010 r., nr 11, poz. 67.

Ustawa z dnia 6 września 2001 r. o dostępie do informacji publicznej, t.j. Dz. U. z 2019 r., poz. 1429. Ustawa z dnia 12 maja 2011 r. o Krajowej Radzie Sądownictwa, Dz. U., nr 126, poz. 714.

Ustawa z dnia 8 grudnia 2017 r. o zmianie ustawy o Krajowej Radzie Sądownictwa oraz niektórych innych ustaw, Dz. U. z 2018 r., poz. 3.

Ustawa z dnia 10 maja 2018 r. o ochronie danych osobowych, Dz. U. z 2018 r., poz. 1000, 1669; z 2019 r., poz. 730 . 


\section{ORZECZNICTWO}

Wyrok Trybunału Konstytucyjnego z 18 lutego 2004 r. (w sprawie K 12/03).

Wyrok Trybunału Konstytucyjnego z 29 listopada 2007 r. (w sprawie SK 43/06).

Wyrok Trybunału Konstytucyjnego z 16 kwietnia 2008 r. (w sprawie K 40/07).

Wyrok Trybunału Konstytucyjnego z 27 maja 2008 r. (w sprawie SK 57/06).

Wyrok Trybunału Konstytucyjnego z 19 listopada 2009 r. (w sprawie K 62/07).

Wyrok Trybunału Konstytucyjnego z 20 czerwca 2017 r. (w sprawie K 5/17).

Uchwała Sądu Najwyższego z 23 lipca 1992 r., III AZP 9/92. 